as the only essential to a valid marriage. No priestly benediction was required as a condition of validity; mutual consent of the parties sufficed to form a marriage even though no priest were present. It was not until after the end of the ninth century that the Church, the different branches at different times, imposed obligatory ceremonies for the solemnization of marriage; but whatever might be the ceremonies, the chief constitutive element of marriage was still the mutual consent of the parties. Down to a quite recent date (1939) the old practice obtained in Scotland, where it sufficed for a man and woman to declare themselves husband and wife in the presence of witnesses. The Roman Catholic Church altered her law in $5_{5} \sigma_{3}$ by the decrees of the Council of Trent; thereafter no marriage was regarded as valid unless celebrated in the presence of three witnesses, one of whom must be a priest. In England a law of 7754 invalidated all marriage (with some allowance for special licences) unless celebrated in the parish church after due publication of banns. It was not until 1836 that in England secular ceremonies before a registrar were allowed. ${ }^{I}$

For the average Briton, perhaps, the nature of Christian marriage is obscured by the fact that the ceremony in Church is dual: a formula is pronounced by the clergyman which, with the subsequent registration, has a definite legal efficacy by bringing the parties under British law; and upon this formula is superimposed the blessing of the Church which has no legal effect whatever. In France the legal ceremony is performed at the town hall; the blessing is given in church, if at all. The purely religious service in either country sanctifies the marriage but has in itself no legal significance. The essential thing remains what it was in Roman law and what it has been all through Christian history: the mutual consent of the parties.

What, then, is Christian marriage? It is the union of a Christian man with a Christian woman, which, being otherwise valid, now receives the Church's blessing implying that the marriage, in accordance with Christian principles, is by the consent of the parties monogamous and indissoluble. In other words, as some would say: it means marriage between Christians which has the added sanctity of a Christian sacrament. From a legal point of view, there are not two things, different in kind and status, 'matriage' and 'Christian matriage'; there is only one, viz. 'marriage'.

\title{
Marriage by African Law and Custom
}

Mr. Phillips quotes a ruling of the Supreme Court of Kenya in 1917 to the effect that ' a socalled marriage by the native custom of wife-purchase is not a marriage . . ', but points out that for most purposes Native customary unions have always in practice been recognized as marriages in that colony. In the Cape Colony at one time the Courts held that Native marriages were immoral in character and therefore invalid; so that apparently all children born of such marriages were illegitimate in the eyes of the law: the contract of lobola in particular was regarded as ' an immoral transaction'. By the Union Native Administration Act of 1927 a clear-cut distinction is drawn between ' marriage', i.e. under the common law, and ' customary unions', i.e. marriages according to native custom, which are now implicitly recognized. This marks the change in the attitude towards the customary law which obtains elsewhere than in the Union - a step towards the effective integration of African law into the general system. The universal problem of a homogeneous law applicable to a whole population remains to be solved; it may well be that the present legal dualism of common law and native law will gradually give way to an assimilation of the two systems. But under present conditions, and especially in regard to relationships such as marriage, the recognition of the customary African law is a necessity. In the opinion of many (the writer included) the distinction drawn between 'marriage' and 'customary union' is a monstrous piece of snobbery; it should never have been made, and should never be made in future.

I A. T. Macmillan, What is Christian Marriage? (1944), pp. 69 sqq. 
The whole subject of native marriage, as Mr. Phillips says, is plainly in need of full and thorough investigation. He lists a series of questions which call for an answer, such as: What are the essentials of a valid customary marriage? At what precise stage of the marriage celebrations is the transaction to be deemed legally complete? Is transference of bridewealth an indispensable condition? For the Belgian Congo an answer to many questions is furnished by M. A. Sohier in his notable work Le Mariage en droit coutumier congolais (1943). With no pretence to exhausting the subject-he wishes his memoir to be viewed as no more than un relai dans la longue route des chercheurs-he has yet arrived at some conclusions that are well worth studying in all parts of the African field to test their validity. For example, he believes, as the result of his personal experience in the Elizabethville Court of Appeal and extensive inquiries, that African marriage is a complex of two dissociable agreements : an alliance between two groups cemented by the transference of goods from one to the other, and a personal union of two persons symbolized by certain rites such as that of eating together. He also believes that the customary law, in some tribes at least, recognizes and sanctions monogamous union; that indeed there is nothing in customary law which forbids it. Here we may note that, as the abstract of M. Pierre Piron's article on pages 268-9 shows, the new ordinance in the Belgian Congo would legalize a customary monogamous marriage.

The question is: Can State and Church and the Native Authorities agree to the full recognition of Native customary marriage as equally valid with marriage according to European law and custom, the Church adding its blessing when the marriage is contracted by Christians? The answer, as has often been said, will be a test of our attitude to African life.

Personally we believe that a large measure of agreement could be gathered in favour of the following propositions: (1) that marriage according to African custom be recognized as legal, with the corollary that all relevant cases of divorce, disputes as to lobola, \&c., be dealt with by the Native Tribunals; (2) that all customary marriages be registered, whether by a civil official or by a Native Authority; this is strongly advocated by Dr. Shropshire in the book reviewed on pages 270-1; (3) that believing Christians should, on production of the registration certificate, receive the blessing of the Church on their marriage-such blessing to involve no legal consequences but the taking of a vow of lifelong monogamous union; (4) that there be, for the sake of Africans who are exempt from Native law, or who wish to assimilate themselves to a European mode of life, a second form of marriage, identical with that contracted by Europeans; no African to be compelled to adopt this form, but, once the conditions and obligations have been explained and understood by him, he should be bound to abide thereby, i.e. if he contracted a second marriage, of either form, he would be liable to a charge of bigamy, as a European would be.

The argument against recognition of customary marriage runs much as follows: African law is not uniform; it is difficult in any instance to say what the law is, for even experts, including Africans, cannot always define it; that it is out-moded, not being in accordance with changed conditions; that it allows polygamy and easy divorce; that it fails to protect the wife and the widow; that the marriage is not an individual but a group union; that while in fact monogamous marriages among Africans are in the majority they are not necessarily monogamous in intention-this Mr. Phillips judges to be the real stumbling-block. The Church rightly has regard to the intention of those who come to be married; but would anyone dare to say that all the thousands of English men and women who are married every year in church intend to live together till death doth them part, without any reservation?

No doubt many of these arguments will be urged by some writers of our articles and rebutted by others; there is substance in them; but let us remember that African law is not static; it is continually being modified under the stress of modern conditions. Mr. Phillips believes that, provided any suspicion as to ulterior motives were allayed, the responsible 
representatives of African opinion to-day would not be opposed to the idea of giving legal recognition in native law to a contract of monogamy. He quotes the unanimous opinion of the Meru Local Native Council (" there is no tribe which clings more tenaciously to its indigenous institutions ') in favour of adapting or interpreting Meru law in such a way as to grant recognition to the institution of monogamy. And Mr. Phillips recommended in his Report that research and planning be instituted with a view to the possibility of incorporating provision for contractual monogamy within the systems of African law. He believes that progressive Africans generally would be in favour of the recognition of monogamy by native law. According to $M$. Sohier there are precedents in the law of some tribes for this recognition: he instances the fairly widespread pact of lusalo which renders the marriage indissoluble and forbids the husband to take a second wife.

If African law requires investigation, so does the effect of endeavouring to force European law upon people who are not prepared for it, who do not understand it, who have their own laws. An African Christian in British colonies is normally bound to use a standardized English law of marriage and divorce, the divorce law being that obtaining in 1905 without the subsequent amendments. The marriage law prohibits his marrying persons whom by his own law he is allowed to marry, and permits him to marry other persons union with whom is regarded by his own people as incest.

We welcome the announcement that the International Missionary Council (Protestant) is considering the possibility of attempting a study of African marriage customs and has asked Mr. J. Merle Davis, Director of the Department of Social and Economic Research, to undertake a preliminary exploration of the subject. We trust that the articles we publish may help to further this inquiry.

\section{Handbook of African Languages}

A REPORT of progress during the year ending 3 I May 1946 was presented to the Bureau of the Institute at its meeting on 27 June. Considerable progress has been made in the course of the second year's work; a scheme for the terminology and method of classification to be employed throughout the Handbook was recommended by the Sub-Committee appointed to consider these questions, and approved by the Linguistic Advisory Committee (see Africa, xvi. 3, pp. I 56-9). Miss Bryan has completed her study of the material relating to the languages of the Anglo-Egyptian Sudan, Ethiopia, Eritrea, the areas south and east of Lake Chad, the north-east area of the Belgian Congo, and the northern parts of Uganda and Kenya, and her notes on the Semitic, Cushitic, Nilotic, and Nilo-Hamitic languages of these areas, together with comprehensive bibliographies, will shortly be published. Dr. Malcolm Guthrie has completed his Classification of Bantu Languages, which is now being prepared for publication. M. Nicolas has been working in Paris on the languages of French West Africa, including Fula, Mandingo, Wolof, Serer, Bambara, and Hausa. Father Santandrea has been engaged on research in the Bahr el Ghazal province of the AngloEgyptian Sudan, and it has been suggested that he should undertake a further field-study in Equatoria Province, Southern Sudan.

\section{Ethnographic Survey}

Work on the Ethnographic Survey has gone forward as material and personnel have become available. For West Africa considerable progress has been made, particularly as regards Nigeria. A draft section on the Ibo-speaking people has been prepared, and similar sections on the Ibibio, Yoruba, and Tiv groups are in hand. A classified list and index of the ethnic groups in Nigeria is being assembled from published and other available material in order to clarify the confused nomenclature. In the Gambia, the preliminary survey of the ethnic 